\title{
Literatura populară la Dunărea de Jos
}

\author{
Drd. NICOLA (NOTARESCU) Eugenia \\ Universitatea „Dunărea de Jos” din Galați
}

\begin{abstract}
Based on the studies and researches undertaken in the southern part of Moldova, we can consider the folk creation in the area of Galați rich and varied, continuously enriched with new "productions" of an increasingly artistic value. We noted the existence of several folkloric areas and, depending on this, different creations that dominated the folklore of the region: the fabulous epic creation from the lowest part of Siret (fantastic ballad, anti-Ottoman, anti-feudal ballad) and the poetry of the secular caroling, close to the heroic old song. In the poetic language of lyrical song we found fundamental themes like love, sorrow, grief, joy, alienation. Research shows that at the end of the 19th century, the epic song in the Covurlui area entered in a "dissolution" phase, living only from the accumulations of the past.
\end{abstract}

Key words: literature, folklore, song, popular, creation

Ca gen literar lirica populară este „un ansamblu de moduri artistice slujind la răsfrângerea directă a sufletului oamenilor din mase" 238 sau „ffelul cum simte, intelege poporul lumea și viata ". 239 Modalitatea este simplă, ca o confesiune atunci când exprimă tristetea , jeluim-as jelui, jeluim-as si n-am cui" sau bucuria "câtu-i lumea pe sub soare, nu-i bine ca-n sezatoare". ${ }^{240}$ Alteori poate avea forma unei comunicări sau unei adresări: „,măi Bădiță moldovene, vin la maica de mă cere". Se constată cu ușurință că poeziile lirice populare sunt, în general, scurte, ca niste ,izbucniri ale preaplinului sufletesc" 241 , lirica populară fiind considerată „,nu numai expresia vieții sufletesti profunde a omului, dar și forma de artă cea mai puțin tradițională" care se transformă în mijloacele ei stilistice în funcție de necesitatea individului de a se exprima cât mai nestânjenit pe sine.

238 Papadima Ovidiu, Literatura Populară Română, Editura pentru Literatură, București 1968, pag. 13

${ }^{239}$ Ibidem, pag. 13

${ }^{240}$ Ibidem, pag. 13

${ }^{241}$ Ibidem, pag. 13 
Lirica folclorică românească nu-și găsește o definiție în popor, omul simplu nefiind preocupat de problema genurilor literare. Cea mai veche denumire care ar fi proprie liricii este aceea de cântec, în mod special cântecul bătrânesc.

În ce priveste mijloacele de expresie artistică, doina și cântecul se contopesc, așa cum remarca Ovidiu Papdima, dând naștere cântecului liric profan, ca gen poetic, împreuna cu cântecele de joc și strigăturile.

Cântecul este alcătuit din două elemente, la fel de importante, cărora creatorul popular le-a acordat deopotrivă aceeași atenție: melodia și textul, amândouă având valoare și semnificație, devenind aproape inseparabile. Doina și cântecul reprezintâ „dimensiunea gravă a vieții sufletești oglindită în poezie" 242 , spre deosebire de strigăturile sau cântecele de joc, care aduc o față a voioșiei și bucuriei din viața omului simplu.

Poezia lirică creează o imagine a universului moral, încărcat cu sentimente, gânduri sau amintiri, devenind „,arta sincerității prin excelență" 243, creația populară fiind puternic legată de toate aspectele și frământările emoționale ale omului.

Creatorul popular, pentru a arăta cât mai bine ce simte și ce gândeste, se foloseste de imagini din universul în care trăiește, iar toate acestea devin mai apoi universul poetic. Cerul, care reprezintă regretul fetei măritate recent, luna, imaginea îndrăgostitului, apa, care sugereaza durerea femeii aflată printre străini sau chiar ", mersul norilor pe deasupra Dunarii"244, care semnifică sentimentul de părăsire în voia sorții al tinerilor plecați în armată: „,pe marginea Dunării merg feciorii ca norii, blăstămându-și părinții" ${ }^{245}$. O alta imagine des întâlnită este cea a muntelui, care exprimă ideea singurătății, specifică vieții ciobanilor: „La Sfânta Marie Mare, tulesc oile la vale și rămân stânele goale, munte fără oi mărunte" (Tudor Pamfile). ${ }^{246}$ Aceeasi imagine poate sugera și refugiul tinerilor care nu voiau să intre în armata habsburgilor: „munte, munte, piatră seacă, lasă feciorii să treacă, să treacă la ciobanie, să scape de cătănie" 247 , de aceea muntele e simbolul pentru singurătate, dor (ciobani haiduci), dar și a

\footnotetext{
${ }^{242}$ Papadima Ovidiu, Literatura Populară Română, Editura pentru Literatură, București 1968, pag. 66-67

${ }^{243}$ Ibidem, pag. 69

${ }^{244}$ Ibidem, pag. 75

${ }^{245}$ Ibidem, pag 76

${ }^{246}$ Ibidem, pag, 76

247 Ibidem, pag. 77
} 
sentimentului înstrăinării: „, ies din casă, cât la munți, intru-n casă , n-am părinţi" (Tudor Pamfile).

Bogdan P. Hașdeu, în studiile sale de folclor, consemna că literatura populară împrumută uneori de la alte popoare modele și mituri, cum ar fi: balada Miorița, pe care o întâlnim la greci și arnăuți, cea a lui Baba Novac la sârbi, cea despre Doicin pe care o au și bulgarii, iar doina despre „sărmana turturică,, o întâlnim și în Danemarca , Spania și România. Remarcabil la literatura populară este modul în care creația împrumutată este tranformată, căpătând un specific local.

Hașdeu subliniază că literatura populară nu se poate „diseca în niște ramuri atât de speciale și de determinate precum sunt diviziunile și subdivizinuile unei literaturi culte"248, dimpotrivă, specific creației populare este „un amestec în fond și în formă, poezie amalgamată cu proza, istoria cu fabula, idealul cu realitatea cea mai banală, elemente empirice ale tuturor științelor". ${ }^{249}$

Literatura populară se poate încadra în 3 genuri: poetic, aforistic și narativ, iar în literatura populară a românilor predomină genul poetic.

Poezia românească populară se împarte în 7 specii:

- Cântecul bătrânesc, un fel de poem despre fapte vitejești, cu haiduci, având elemente de epopee națională

- Doina, expresia iubirii și a suferinței

- Colindul, un imn religios în care se ascunde păgânismul sub acoperământul teologiei creștine

- Hora, cântec de joc și bucurie

- Vicleemul, forma teatrului primordial în care păpuși reprezintă, într-un mod grosier, ,"drama și mai ales comedia vieții umane" 250

- Descântecul, deseori în proză, dar face parte din genul poetic, din cauza formelor sale. Este poezia cunoscuta ca „medicală”

- Orația, o poezie recitativă cu caracter juridic (întelegeri, tocmeli)

La români se întâlnește poezia populară în genul aforistic și narativ, în proverbe, ghicitori și basme. Lirica populară, inspirată din viață, conservă și

\footnotetext{
${ }^{248}$ Hasdeu, B., P., "Cuvente den bătrîni, II, Cărțile poporane ale românilor în secolul XVI”,cap. "Balada " "Cucul şi turturica»la români, la moravi, la provențali, la reto-romani,la perşi, la turcomani", Bucureşti, 1879, pag. 501-600

${ }^{249}$ Ibidem, pag. 501-600

250 Papadima Ovidiu, Literatura Populară Română, Editura pentru Literatură, București 1968, pag. 130
} 
imagini din trecut, prin personajele din cântecele bătrânești, oameni cunoscuți în popor, care au luptat pentru drept

ate și libertate, și care rămân prin creația populară vii în memoria colectivă. Printre aceștia se numără Horia, Avram Iancu, domnitorul Al. I. Cuza, și chiar Aurel Vlaicu. În amintirea acestor personaje istorice, lirica populară păstrează faptele lor de odinioară, îi evocă cu admirație.

Ion Brezeanu, în urma studiilor și cercetărilor pe care le-a întreprins în zona de sud a Moldovei, consideră creația folclorică din această regiune bogată și variată, îmbogățită continuu cu noi „producții” de o valoare artistică din ce în ce mai ridicată. Creația din această zonă a fost influențată de trecerea drumurilor oierilor transilvăneni din părțile Brașovului, care ajungeau și în împrejurimile Galațiului, într-o epocă istorică în care transhumanța subsista ca fenomen efectiv, cu urmări asupra folclorului.

Cercetările istorice arată că, în partea de miază-zi a ținuturilor Tecuci și Covurlui, în secolul al XVI -lea exista un ținut numit Oltenii, probabil datorită locuitorilor veniți aici din această zona sau de pe malurile Oltului. În zona regiunii Galațiului, folcloristul gălățean remarca existența mai multor zone folclorice și, în funcție de asta, diferite creații care au dominat folclorul zonei: în jos de Siret exista creația epicî dominată de fabulos (balada fantastică, balada anti-otomană, anti-feudală) și poezia urării (colinda laica), având forma apropiată de cântecul bătrânesc eroic. ${ }^{251}$

În zona Dunării s-a găsit „balada dunăreană"-creație artistică a patrimoniului spiritual al populației din această zonă, iar în perioada obștilor sătești s-au găsit colinde și descântece: cântecul epic-eroic, iar în perioada modernă cântecul liric. Și în zona Galațiului, în limbajul poetic al cântecului liric se regăsesc teme precum dragostea, dorul, întristarea, bucuria, înstrăinarea. Zona de sud a Moldovei a fost mai degrabă un "cămin"252 pentru populația de peste munți și din acest motiv nu prea se găsesc cantece de înstrăinare, așa cum se întampla, de exemplu, în Transilvania.

În repertoriul liric al zonei, Ioan Brezeanu regăsește, în special, cântecele de dragoste și dor, frumusețea lor aflându-se „nu atât în bogatia și varietatea epitetelor tropilor și figurilor de stil, cât în sinceritatea sentimentelor, în

251 Brezeanu ioan, La izvoarele cântecului,Editura Casa Creației Populare a Județului Galați, 1969, pag 7-30

${ }^{252}$ Ibidem, pag. 7-30 
limbajul simplu și colorat"253. Lirica zonei conține comparații obișnuite în lirica populară românească, cu trimiteri la mediul înconjurator: flori, copaci, lună, stele, păsări -,,cu cămașa cu flori multe, de tine mândro cusute”, „batista avea o floare, ștergeam fața de sudoare și ochii de lăcrămioare”. ${ }^{254}$

Găsim, ca de altfel în întreaga lirică românească, motivul cosmic al disputei dintre soare și lună, pe tema castității fetelor: „Vine să jure sfântul soare, că nu-s fetele fecioare. Sfânta luna mi-i oprește: -stai tu soare, nu jura! Căci nu le știi dragostea!"255. Prezent în zonă e și cântecul de dor- ,'sentiment polivalent și complex, cu nuanțe și întelesuri greu de explicat"256, pe care poetul popular și-1 închipuie în felurite moduri: „doru-i o grădină mare, are dreptul orișicare să-și aleagă câte-o floare" sau " câte raze sunt pe soare, niciuna nu-i arzătoare ca dorul de fată mare". ${ }^{257}$ Cântecul de dragoste este considerat ,'inima însăși a cântecului liric popular"258, dar în același timp și cel mai bogat gen, aflat în preocupările celor tineri, dar mai ales al fetelor și femeilor. Folcloristul Ilarion Cocișiu citează o relatare din Istoria muzicii în Transilvania:,, La compunerea melodiilor, genul feminin e îndeosebi înzestrat de la natură. La bucrurie și la durere, la muncă și la clacă, femeile își cântă dragostea, necazul, și la fel, în fața mormântului, își jelesc morții”. ${ }^{259}$

Cântecul înstrăinării și al singurătății are ca teme: plecarea de acasă, pierderea părinților sau căsătoria în alt sat; înstrăinatul este „,ca mierla, cucul, garoafa" iar străinul este ,spin, mărăcine, pelin”. 260

„,Rău îi Doamne, cu străinul

Mai amar decât pelinul.

Rău îi Doamne prin străini

Ca desculți printre spini" ${ }^{261}$

${ }^{253}$ Brezeanu ioan, La izvoarele cântecului, Editura Casa Creației Populare a Județului Galați, 1969, pag 7-30

${ }^{254}$ Ibidem, pag 7-30

255 Ibidem, pag 7-30

256 Ibidem, pag 7-30

257 Ibidem, pag 7-30

258 Papadima Ovidiu, Literatura Populară Română, Editura pentru Literatură, București 1968, pag. 130

259 Ibidem, pag. 130

${ }^{260}$ Brezeanu ioan, La izvoarele cântecului, Editura Casa Creației Populare a Județului Galați, 1969, pag 7-30

${ }^{261}$ Ibidem, pag. 7-30 
,Lirica înstrăinării este formată din cântecele de jale ale fetelor măritate ,în străini" cre își plâng despărțirea de familie:

,Strugurel bătut de brumă,

Rău îi, Doamne, făr-de mumă !

Strugurel bătut de piatră,

Rău îi, Doamne, făr-de tată!

De-ai călca din piatră-n piatră,

Din străin nu îți faci tată

De-ai călca din urmă-n urmă,

Din străin nu mai faci mumă !"262

În podișul Covurluiului erau cândva păduri de stejari, astăzi câteva rămășițe în pădurile Adam, Gârboavele, Tălășman, locuri unde, în sec al 18lea, începutul secolului al 19- lea, haiducia era prezentă ca formă de protest. Așa apare căntecul haiducesc, care în zona Galațiului conține motive similare celor din Oltenia și Muntenia. Folcloristul Brezeanu, în studile sale, constată că acest cântec din Covurlui folosește stilul narativ retoric și se apropie de cântecul liric din Oltenia și Muntenia. Sunt împletite, în unele variante, motive proprii cântecului haiducesc, ca în varianta „Mă lăsai din deal în luncî" din Slobozia Conachi, în care se unesc șase motive, iar alteorise regăsesc motive ale cântecului de dragoste și dor, sau de înstrăinare:

„,Roibule cu părul tuns,

Du-mă-n șa pe Prut în sus,

Du-mă printre bolovani și mă scapă de dușmani,

Du-mă printre mărăcini și mă scapă de străini". ${ }^{263}$

Se mai găsesc în zonă cântece de cătănie, cântecul de război, destul de rar și cântecul epic, cu numele de „cântec bătrânesc", sau „,baladă”.

Cercetările realizate până în nordul județului au descoperit existența unui repertoriu de 30 de cântece bătrânești, publicate de Tudor Pamfile în 1913, care păstrau caracterul de poem și un personaj, haiduc local, Dragoș, căruia i se dedică un cantec în 199 de versuri, cunoscut în zona comunei Țepu:

„Foaie verde salamale

Ici în vale, mai în vale

${ }^{262}$ Papadima Ovidiu, Literatura Populară Română, Editura pentru Literatură, București 1968, pag. 104

${ }^{263}$ Brezeanu ioan, La izvoarele cântecului, Editura Casa Creației Populare a Județului Galați, 1969, pag 7-30 
Se plimba Dragoș călare

De potera habar n-are". ${ }^{264}$

Cântecul eroic dunărean se naște în urma frământărilor din viața trăită la malul Dunării, având ca tema lupta localnicilor cu cotropitorii Imperiului Otoman. Poetul popular zugrăvește dramele locuitorilor prădați, drame ale fetelor răpite sau ale mamelor supuse la chinuri. George Călinescu considera baladele dunărene „poezii rupte din viață, cu mare profunzime de culoare locală, picturi pline de detalii, documnete care colcăie de realism" 265 . Personaje din literatura populară ridicate la rang de eroi îi găsim pe Novăceștii, Vâlcan, Badiu, Frații Chirei, care au au dat numele cântecelor auzite prin porturile Galați și Brăila, și care au ajuns ulterior în Oltenia, Banat și în Munții Vrancei. Viața în porturilor de la Dunăre, apariția celor îmbogățiți peste noapte, a devenit de asemenea temă :

Colo-n schelă, la Galați,

Lipovenii sunt bogați,

Cazaclii îngrășați,

Negustorii încărcați,

De postavuri ungurești,

De arme persienești,

Și de blăni lipovenești." 266

Transilvănenii ajunși în zona Galațiului au adus cu ei balada Miorița, care a fost găsită într-o formă specifică locului, la Hanul Conachi, în anii 60, în satul Vădeni sau comuna Liești.

Cel mai răspândit cântec din satele județului Galați este cunoscut sub numele de „Peneș”, ,Ghiță”, ,'Cătănuța”, , ,Vidra” etc. Tema cântecului este infidelitatea conjugală, de care Vidra este acuzată de catre soțul sau, Ghiță Cătănuță.

Folcloristul Tudor Pamfile a cules folclor din nordul județului Galați, în volumul său „, Cântece de țară”, apărut în 1913, din satul în care s-a născut, Țepu, valorificând astfel cântece de dragoste, basme, snoave, legende, jocuri de copii, cimilituri și altele. Cercetările arată că, la sfârșitul secolului al 19lea, cântecul epic din zona Covurluiului a început să intre în faza „disoluției”, trăind doar din acumulările vremurilor trecute. Cântecele

${ }^{264}$ Ibidem, pag. 7-30

265 Călinescu George, Istoria literaturii romîne, vol.1, Editura Academiei Române, București,1964, pag. 219

266 Brezeanu Ioan, Nadoleanu Gh, Pe-un picior de plai, Culegere de folclor poetic din Regiunea Galați, Casa regională a creației populare, Glați, 1967, pag. 4 
bătrânești, spre exemplu, se mai auzeau în 1893 numai pe la bâlciuri și iarmaroace, când le cântau lăutarii textele. ${ }^{267}$

\section{Bibliografie:}

\section{CULEGERI}

Băncescu Iuliana, Panaitescu Laura Elisabeta, Obiceiuri de iarnă la Dunărea de jos, Editura

Centrului cultural „Dunărea de Jos”, 2017

Brezeanu Ioan, Nadoleanu Gheorghe, Pe-un picior de plai - Culegere de folclor poetic din

Regiunea Galați, Editura Muzeul de Istorie Galați, 1967

Brezeanu Ioan, La izvoarele cântecului, Editura Muzeul de Istorie Galați, 1969.

\section{BILIOGRAFIE TEORETICĂ ȘI CRITICĂ}

Bârlea Ovidiu, Poetică folclorică, București, Ed. Univers, 1979.

Bârlea, Ovidiu, Folclorul românesc, II, București, Editura Minerva, 1983.

Bernea, Ernest, Cadre ale gândirii populare românești, București, Editura Cartea Românească, 1985

Brezeanu Ioan, Colindele de la Dunărea de Jos. Ritualuri. Poetică, Editura Fundaţiei Universitare "Dunărea de Jos", 2000

Caracostea, Dumitru, Bîrlea Ovidiu, Problemele tipologiei folcorice, Editura Minerva, București,1971

Caraman Petru, Studii de folclor, București, Editura Minerva, 1987.

Călinescu, George, Istoria literaturii române de la origini până în prezent, București, Editura Minerva, 1982

Hașdeu, B. P., Studii de folclor, Ediție îngrijită și note de Nicolae Bot, Prefață de Ovidiu Bârlea, Cluj - Napoca, Editura Dacia, 1979 Hașdeu, B. P., Etymologicum Magnum romaine, București, 1887.

Pamfile Tudor, Mitologie românească, București, Editura All, 1997.

Pamfile Tudor, Sărbătorile la români- studiu etnografic, Editura Saeculum, București, 1997

Papadima Ovidiu, Literatura populară română, București, Ed. Minerva, 1968. Papadima Ovidiu, O viziune românească a lumii, Editura Saeculum, București, 1995

267 Brezeanu ioan, La izvoarele cântecului, Editura Casa Creației Populare a Județului Galați, 1969, pag. 7-30 
Papahagi, Tache, Mic dicționar folcloric. Spicuiri folclorice și etnografice comparate, Ediție îngrijită, note și prefață de Valeriu Rusu, București, Editura Minerva, 1979.

Ruxăndoiu Pavel, Folclorul literar în contextul culturii populare românești, Bucureti, Editura Grai și Suflet - cultura Naţională, 2001

Tomașevski, Boris, Teoria literaturii. Poetica, București, Editura Univers, 1973 Ursache Petru, Poetică folclorică, Iași, Editura Junimea, 1975

Vrabie Gheorghe, Balada populară română, București, Editura Academiei, 1966 Vrabie Gheorghe, Eposul popular românesc, București, Editura Albatros, 1980 Vrabie Gheorghe, Retorica folclorului, București, Ed. Minerva, 1978

Vrabie Gheorghe, Din estetica poeziei populare române, București, Editura Albatros, 1990

Vrabie Gheorghe, Poetica Mioriţei, București, Editura Academiei, 1984

Vrabie Gheorghe, Balada populară română, București, Editura Academiei, 1966 